\title{
Evaluation of Post Emergence Herbicides for Control of Annual Weeds at Higher Seed Rate of Wheat
}

\author{
Bogale Ayana \\ Ethiopian Institute of Agricultural Research, Holeta Agricultural Research Center, \\ P.O. BOX 31, Holeta, Ethiopia
}

\begin{abstract}
Wheat is one of the most important food security crops that cultivated from small to large scale farms in Ethiopia. However, its productivity has been limited due to various abiotic and biotic factors including weeds. The aim of the study was to investigate the effects of post emergence herbicides application on weed management and productivity of wheat. Four types of herbicides 2,4-D1lt ha- ${ }^{-1}$ Pyroxulam $0.51 \mathrm{tha}^{-1}$, Florasulam $100 \mathrm{ml} \mathrm{ha}^{-1}$ and Florasulam+ Amirpyrolid 33gm ha ${ }^{-1}$ along with control a weedy check were laid out in Randomized Completely Block Design with three replications. A total of identified 12 weed species were recorded $86 \%$ broad and $14 \%$ grass weeds. Relative weed density also indicated that the field was highly infested by Galinsoga pulviflora Cav. but the lowest infestation of Guizotia scabra(Vis) Chiov was recorded in the field. Results also revealed that significant effects of post emergence herbicides application for all the traits studied except number of seeds per spike. The minimum dry biomass weeds $\left(88.33 \mathrm{~kg} \mathrm{ha}^{-1}\right)$ and the highest weed control efficiency $(78.60 \%)$ were recorded from the Pyroxulam. The highest number of productive tillers $\left(133.33 \mathrm{~m}^{-2}\right)$, stand count $\left(414.33 \mathrm{~m}^{-2}\right)$,seeds per spike (76.48), thousand grain weight $(42.60 \mathrm{~g})$, grain yield $\left(4346.58 \mathrm{kgha}^{-1}\right)$ and biological yield $(12100 \mathrm{~kg} \mathrm{ha-}$ ${ }^{1}$ ) were recorded from Pyroxulam while the lowest values were observed from the weedy check. Therefore, it can be concluded that Pyroxulam effectively managed weeds and gave maximum yield which could be recommended for the test environment. Since the experiment was conducted in one location and for single season, it should be repeated over seasons or multi locations for best recommendation.
\end{abstract}

Keywords: application, effect, herbicides, maximum, Pyroxulam

DOI: $10.7176 /$ JEES/11-3-05

Publication date:March $31^{\text {st }} 2021$

\section{INTRODUCTION}

Wheat (Triticum aestivum L.) belongs to the family Poaceae and the genus Triticum. The global annual wheat production is 731.6 metric tons from an area of 215.87 million hectares giving an average yield of 3.39 metric tons $\mathrm{ha}^{-1}$ (USDA,2019).In Ethiopia, it is one of the major staple and strategic food security crop with an average annual production and productivity of 4.64 $\mathrm{MT}$ and 2.73 tons $^{-1}$ respectively (CSA,2018). Wheat has great nutritional value and contains starch (60-90\%), protein (11-16.5\%), fat (1.5-2\%),inorganic ions (1.2-2\%) and vitamins (Ali et al., 2014). Bread wheat is known to be a major source of energy and protein. Traditionally the crop is used for making Dabo, Dabokolo, Genfo, Kinche and other types of foods. The straw is good source for animal feed and is also used for hatching roofs (Mathewos et al., 2012).

Although wheat has a great nutritional and economic importance, its productivity has been constrained due to various biotic and abiotic factors(Haidar et al.,2014).Among the biotic factors weeds are one of the major constraints in wheat production as they reduce productivity due to competition, allelopathy and by providing habitats for pathogens as well as serving as alternate host for various insects, fungi and increase harvest cost (Abbas et al.,2009).Studies indicated that crop losses due to weed competition throughout the world are greater than those resulting from combined effects of insect pests and diseases (Amare et al.,2014). The yield loss caused by weed infestations in wheat ranges from 10-65\% depending up on the weed species, their density and environmental factors(Gezu and Soboka,2001;Oerke and Dehne,2004).

The weed controlling methods utilized so far are laborious, tiresome and expensive due to increasing cost of labor, draft animals and farm implements. To date, the use chemical weed control has becoming popular worldwide and in Ethiopia in particular mainly due to scarcity or expensive labor during peak of growing season and relatively higher weeding cost (Marwat et al.,2008). However, the choice of most appropriate herbicide, proper time of application and proper dose is an important consideration for lucrative returns(Khalil et al.,2008).In addition, continuous use of a single herbicide or herbicides of the same family or mechanism of action eventually resulted in weed resistance, herbicide persistence as well as the buildup of toxic residues in food chain, toxic effects to humans and animals (Qasem,2009).

Previous studies showed application of herbicides decreased dry weight of weeds significantly compared to dry weight in non-treated plots and increased yield components and grain yield (Akhtar et al., 1991; Ahmed et al., 1993; Bibi, et al., 2008). However, information of broad spectrum herbicides on weed control and productivity of wheat remains limited in Ethiopia. The absence of this information has prevented better understanding of the efficacy of different herbicides for various weed flora and identification appropriate herbicides in wheat. Hence, 
addressing issues of weed control in wheat is indispensable. Therefore, the purpose of this study was to investigate the effects of post emergence herbicides application on weed management and productivity of wheat.

\section{MATERIALS AND METHODS}

\section{Description of the study area}

Field experiment was conducted during the 2018/19 main cropping season under rain fed conditions at Holeta Agricultural Research Center. Holeta is located $33 \mathrm{~km}$ west of Addis Ababa at an elevation of 2400m.a.s.1 and within the geographic coordinates of $9^{\circ} \mathrm{o}^{\circ} \mathrm{N}$ land $38^{\circ} 3^{\circ} \mathrm{E}$. The area receives a mean annual rain fall of $1144 \mathrm{~mm}$ with mean minimum and maximum temperatures of $6^{\circ} \mathrm{c}$ and $22{ }^{\circ} \mathrm{c}$,respectively (EIAR,2018). The soil of the experimental field is clay loam i with $\mathrm{pH}$ of 6.65 , organic carbon $(2.26 \%)$, available Phosphorus $\left(14.17 \mathrm{mg} \mathrm{kg}^{-1}\right)$ soil, total nitrogen $(0.12 \%)$ and cation exchange capacity $\left(17 \mathrm{Cmol} \mathrm{kg}^{-1}\right)$ (EIAR,2018). The edaphic and climatic conditions observed during the trial period were favorable for the exuberant growth of numerous weed species that competed with the crop plants.

\section{Treatments and experimental design}

The treatments included four types post emergence herbicides (Agro 2,4-D amine 720g/L(1Lha ${ }^{-1}$ ), Pallas 45 OD $\left(0.5 \mathrm{~L} \mathrm{ha}^{-1}\right)$, Derby $175 \mathrm{SC}\left(100 \mathrm{ml} \mathrm{ha}^{-1}\right)$, Lancolet $450 \mathrm{WG}\left(33 \mathrm{gha}^{-1}\right)$ plus weedy check. The experiment was laid out in a Randomized Complete Block Design with three replications.

\section{Experimental procedure and crop management}

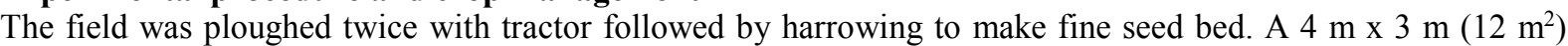
gross plot size was used as the experimental unit accommodating 15 rows of each $4 \mathrm{~m}$ length. Well popularized wheat variety 'Dendea' $200 \mathrm{~kg} \mathrm{ha}^{-1}$ was used as a test crop. Seeds were drill planted in rows at $20 \mathrm{~cm}$ spacing between rows. The experimental area was fertilized with the recommended rate of $55 \mathrm{~kg} \mathrm{ha}^{-1}$ of N and $182 \mathrm{~kg}$ ha${ }^{1}$ of $\mathrm{P}_{2} \mathrm{O}_{5}$ that were applied in the form of Urea $(46 \% \mathrm{~N})$ and DAP $\left(18 \% \mathrm{~N}, 46 \% \mathrm{P}_{2} \mathrm{O}_{5}\right)$, respectively. Nitrogen fertilizer was applied at two doses (split application) i.e. 2/3 of it was applied at time of sowing by mixing with full dose of Nitrogen and the remaining 1/3 was applied at tillering stage. Herbicides were applied at post emergence stage (30 DAE) with the help of knapsack sprayer nozzle size of 350um while the volume of water was $200 \mathrm{~L} / \mathrm{ha}^{-1}$ pressurized at $40 \mathrm{psi}$. All other management practices were uniformly applied to all plots as per the recommended practices.

\section{Data collection}

Data regarding the kind of weed species and their densities were determined at 25 days after sowing i.e., before the application of herbicides) from four $0.25 \mathrm{~m} \mathrm{x} 0.25 \mathrm{~m}$ quadrats randomly placed in each plot. After the weed flora was categorized as grasses and broad leaf weeds, identification was done using a weed identification guide for Ethiopia (Stroud and Parker, 1989). The aboveground dry weed biomass harvested from each quadrat placed into paper bags separately and sun dried before oven drying at a $65{ }^{\circ} \mathrm{C}$ for 48 hours and subsequently the dry weights were measured. Weed control efficiency (WCE) was determined by the formula, $W C E \%=$ $\frac{W D C-W D P}{W D C} \times 100$

where, WCE $=$ Weed Control Efficiency, WDC $=$ Weed Dry weight in Control Plot and DWP $=$ Weed Dry weight in Particular treatment (Davasenapathy et al.,2008). Plant height was taken with a meter from 4 randomly taken and pre-tagged plants in each net plot area from the plant base to the tip of the spike excluding of awns at physiological maturity and the average was used for the analysis.

Spike length was taken with a ruler from 4 randomly taken and pre-tagged plants in each net plot area from the base of the spike to the tip of the spike excluding of awns at physiological maturity and the average was used for the analysis. Number of fertile tillers was counted from five rows with the length of $1 \mathrm{~m}$ randomly taken in each net plot area and was converted into $\mathrm{m}^{2}$ at harvest. Number of seeds per spike was determined from randomly taken 4 spikes per plot. Thousand grain weights were measured from the bulk of threshed produce from the net plot area and their weight recorded. Biological yield was determined by taking the total weight of the harvest from each net plot area after sun dried the whole aboveground biomass. Grain yield was measured after threshing the sun dried plants harvested from each net plot and the yield was adjusted at 12.5\% grain moisture content (Amare et al., 2014). Harvest index was calculated by the formula, $\mathrm{HI} \%=\frac{\text { Grain Yield }}{\text { Total above ground dry biomass }} X 100$.Yield loss was also calculated by $\mathrm{YL} \%=\frac{M G Y T-G Y P T}{M G Y T} X 100, \mathrm{YL}=$ yield loss, MGPT=maximum grain yield of particular treatment and GYPT=grain yield of particular treatment. 


\section{Statistical analysis}

After checking the assumptions of ANOVA using descriptive and analytical statistics, data were subjected to analysis of variance using the GLM procedure of SAS (SAS 9.3 version). When the treatment effects were significant, means were compared using Fisher's LSD test at 5\% level of significance (Gomez and Gomez, 1984).

\section{RESULTS AND DISCUSSION}

\section{Composition of weed flora and density in the experimental field}

The weed community comprised of both broadleaf and grass weeds which were classified in to eight major families. Out of total weeds species present in the experimental field $86 \%$ were annual broadleaf weeds while $14 \%$ were annual grasses weeds. The maximum relative weed density in the field was G.pulviflora (22.91\%) followed by P.nepalense (18.55\%) while minimum relative weed density was recorded from G. scabra (0.98\%) (Table -1).

Table 1.Common names, scientific names, densities and life forms of weed species in experimental field

\begin{tabular}{|c|c|c|c|c|}
\hline Scientific names & Families & $\begin{array}{l}\text { Weed density } \mathrm{m}^{-2} \\
\text { before spray }\end{array}$ & $\begin{array}{l}\text { Relative } \\
\text { Weed } \\
\text { Density (\%) }\end{array}$ & Life form/category \\
\hline Arthraxon prinodes L. & Poaceae & 11.03 & 5.35 & Annual (grass) \\
\hline Setaria pumila L. & Poaceae & 15.12 & 7.34 & Annual (grass) \\
\hline Phalaris paradoxa L. & Poaceae & 2.69 & 1.31 & Annual (grass) \\
\hline Galinsoga pulviflora Cav. & Compositae & 47.18 & 22.91 & Annual (broad leaf) \\
\hline Corrigiola capensis Wild & Caryophylaceae & 24.35 & 11.82 & Annual (broad leaf) \\
\hline Guizotia scabra(Vis)Chiov & Compositae & 2.03 & 0.98 & Annual (broad leaf) \\
\hline Oxalis corniculata HBK & Oxalidaceae & 14.00 & 6.79 & Annual (broad leaf) \\
\hline Plantago lanceoleta L. & Plantaginaceae & 9.51 & 4.62 & Annual (broad leaf) \\
\hline Polygonum nepalense L. & Polygonaceae & 38.20 & 18.55 & Annual (broad leaf) \\
\hline Raphanus raphanistrum $\mathrm{L}$. & Brassicaceae & 7.50 & 3.65 & Annual (broad leaf) \\
\hline Spergula arvensis L. & Caryophylaceae & 10.00 & 4.86 & Annual (broad leaf) \\
\hline Cyanotis barbata D.Don & Commelinaceae & 24.35 & 11.82 & Annual (broad leaf) \\
\hline
\end{tabular}

\section{Dry biomass of weed}

The applications of herbicides were significant on dry biomass of weeds. The highest dry biomass of weeds (411.66 $\mathrm{kg} \mathrm{ha}^{-1}$ ) was recorded in weedy check whereas the minimum (88.33 $\left.\mathrm{kg} \mathrm{ha}^{-1}\right)$ was recorded due to Pyroxulam application (Table-2).

The application of herbicides 2, 4-D, Florasulam and Florasulam + Amirpyrolid revealed that statistically no significant difference. The minimum dry biomass of broad leaf weeds at Pyroxulam might be related to the activity of broad spectrum herbicides and also due to the ability of the herbicide in reducing weed density by killing both broadleaf and narrow leaf weeds by affecting the physiological process of those weeds resulted in mortality of weeds that remained in field.

This finding was similarly with Nadeem et al. (2006) and Munsif et al. (2009) who concluded that maximum weed density in weedy check can be attributed to unchecked growth, while application of herbicide caused mortality of weed resulting in lower weed density at harvest. Unavailability of nutrients in control and suppression by well-developed wheat plants resulted in similar weed density.

Table 2.Effects of herbicides on dry biomass of weed and weed control efficiency

\begin{tabular}{lcc}
\hline Treatments & Dry weed biomass $\left(\mathrm{kg} \mathrm{ha}^{-1}\right)$ & Weed control efficiency $(\%)$ \\
\hline 2,4-D & $113.33 \mathrm{~b}$ & $72.55 \mathrm{c}$ \\
Pyroxulam & $88.33 \mathrm{c}$ & $78.60 \mathrm{a}$ \\
Florasulam & $106.66 \mathrm{bc}$ & $73.76 \mathrm{bc}$ \\
Florasulam + Amirpyrolid & $95.00 \mathrm{bc}$ & $76.99 \mathrm{ab}$ \\
Weedy check & $411.66 \mathrm{a}$ & $0.00 \mathrm{~d}$ \\
\hline LSD $(0.05)$ & 22.83 & 4.32 \\
CV $(\%)$ & 7.44 & 3.77 \\
\hline
\end{tabular}

\section{Weed control efficiency}

Weed control efficiency was influenced by herbicides application. The maximum weed control efficiency was recorded at Pyroxulam (78.60\%) while no weed control efficiency at weedy check (Table -2).

The application 2,4-D and Florasulam showed that statistically no significant difference. Similarly, the application of Pyroxulam and Florasulam + Amirpyrolid revealed that statistically no significant difference. The higher weed control efficiency at Pyroxulam might be related to lowest dry biomass of weeds which exhibited that the ability of the herbicides killing various weeds species in wheat.

Additionally, the result also revealed that broad spectrum herbicides increased weed control efficiency due 
to limited weed growth but at low weed control efficiency as a result of severe inter and intra specific competition and higher weed biomass. This might be related to the activity of broad spectrum of the herbicide against both broad and grassy weeds as compared to other herbicides application. These findings are similar with who reported that herbicides with broad spectrum provided better weed control efficiency than control treatment (Ashiq et al.,2007).Tana et al. (2018) reported that the high control efficiency indicated that the weed were controlled when they are young or before they accumulated more dry matter by competing with the crop plants.

\section{Plant height}

The application of different herbicides had significant effect on plant height. The maximum plant height was recorded from weedy check plots $(109.00 \mathrm{~cm})$ followed by Florasulam + Amirpyrolid $(105.83 \mathrm{~cm})$ while the minimum plant height $(101.66 \mathrm{~cm})$ was obtained from application of Pyroxulam (Table -3$)$.

The application of 2,4-D, Pyroxulam and Florasulam showed that statistically no significant differences. Correspondingly, Florasulam and Florasulam + Amirpyrolid exhibited no significant differences. The tallest plants $109 \mathrm{~cm}$ at weedy check indicated that the competition of weeds. The result clearly showed that plant attained its maximum height where the competition was severe for light between crop as well as weed but at lower competition, plant could not invest larger resources to attain its maximum height. Similar findings was reported from Bibi et al (2008) who reported that in weedy check the wheat crop invested photosynthate in attaining the vegetative superiority by shading weeds. These findings was contradicted with the work reported by Khalil et al. (2009) who concluded that plant height is strongly under genetic control and but not affected by herbicides application. Plant height is a varietal character more affected by the genotype than by the environment. However, interaction of factors to some extent significantly altered plant height (Safdar et al., 2011).

\section{Number of tillers}

The numbers fertile tillers $\mathrm{m}^{-2}$ was significantly affected by different herbicidal application. Maximum number of fertile tillers $\left(132.33 \mathrm{~m}^{-2}\right)$ were recorded from application of Pyroxulam while the minimum number of fertile tillers $\left(82.00 \mathrm{~m}^{-2}\right)$ was recorded at weedy check plots (Table - 3).

The application of 2,4-D and Pyroxulam caused statistically no significant difference. Moreover, the application of Florasulam and Florasulam + Amirpyrolid showed that statistically non-significant. The maximum number of fertile tillers at Pyroxulam could be related with lower dry biomass of weeds, better weed control efficiency that resulted in less inter and intra specific completion of weeds with crop plants for water, nutrients and other growth factors and also due to the optimum space for wheat plants to flourish and produce fertile tillers up to their potential but the probable reason of lower number of fertile tillers in other interaction could be grasses escaped from their phytotoxicity and were competitive with wheat resulting in lower tillers. Lower number of fertile tillers in weedy check treatment can be attributed to higher weed density that resulted in competition for plant growth resources.

Dalga (2016) reported similar results that under low competition between weeds and crop for resources that enhanced productive tillers. Asad et al. (2017) also stated that increase in number of fertile productive tillers relatively better weed control which ultimately facilitated by more translocation of photosynthate towards reproductive growth due to lower weed wheat competition. Hussein et al.(2013) also reported that effective weed control methods could reduce dry matter of weed and increased number of wheat productive tillers.

\section{Stand count}

The stand count $\mathrm{m}^{-2}$ was significantly affected by different herbicidal application. Maximum number of stand count $\left(414.33 \mathrm{~m}^{-2}\right)$ were recorded from application of Pyroxulam while the minimum number of stand count (154.33 $\mathrm{m}^{-2}$ )was recorded at weedy check plots (Table -3 ).

The application of 2, 4-D and Pyroxulam caused statistically no significant difference on stand count. Correspondingly, the application of Florasulam and Florasulam + Amirpyrolid showed that statistically nonsignificant. The maximum number of stand count at Pyroxulam could be related with lower dry biomass of weeds, better weed control efficiency that resulted in less inter and intra specific completion of weeds with crop plants for water, nutrients and other growth factors and also due to the optimum space for wheat plants to flourish and produce fertile tillers up to their potential but the probable reason of lower number of fertile tillers in other interaction could be grasses escaped from their phytotoxicity and were competitive with wheat resulting in lower tillers. Lower number of fertile tillers in weedy check treatment can be attributed to higher weed density that resulted in competition for plant growth resources.

Dalga (2016) reported similar results that under low competition between weeds and crop for resources that enhanced productive tillers. Asad et al. (2017) also stated that increase in number of fertile productive tillers relatively better weed control which ultimately facilitated by more translocation of photosynthate towards reproductive growth due to lower weed wheat competition. Hussein et al. (2013) also reported that effective weed control methods could reduce dry matter of weed and increased number of wheat productive tillers. 
Table 3. Effects of herbicides on plant height, number of tillers and stand count

\begin{tabular}{lccc}
\hline Treatments & Plant height $(\mathrm{cm})$ & Number of tillers & Stand count $\left(\mathrm{m}^{-2}\right)$ \\
\hline 2,4-D & $102.50 \mathrm{c}$ & $130.00 \mathrm{a}$ & $411.66 \mathrm{ab}$ \\
Pyroxulam & $101.66 \mathrm{c}$ & $132.33 \mathrm{a}$ & $414.33 \mathrm{a}$ \\
Florasulam & $102.66 \mathrm{bc}$ & $126.66 \mathrm{a}$ & $408.66 \mathrm{~b}$ \\
Florasulam + Amirpyrolid & $105.83 \mathrm{ab}$ & $127.00 \mathrm{~b}$ & $408.88 \mathrm{~b}$ \\
Weedy check & $109.00 \mathrm{a}$ & $82.00 \mathrm{c}$ & $154.33 \mathrm{c}$ \\
\hline LSD $(0.05)$ & 3.19 & 2.67 & 4.47 \\
CV $(\%)$ & 1.62 & 1.18 & 0.66 \\
\hline
\end{tabular}

\section{Spike length}

The application of different herbicides had significant effect on the spike length of wheat. The highest spike length was recorded from application of Pyroxulam $(9.58 \mathrm{~cm})$ followed by the application of 2,4-D $(9.16 \mathrm{~cm})$ but the lowest spike lengths were recorded at weedy check (Table-4).

The application of all tested herbicides produced statistically no significant difference except Florasulam. The maximum spike length recorded at Pyroxulam could be related to effective weed control that resulted in better growing conditions for the crop to utilize resources effectively to produce longer spikes but at weedy check due to severe competition shorter spikes produced.

Similar result was reported from Tana et al. (2018) continuous increase in spike length which might be attributed to relief of wheat plants from weed competition leading to better growing conditions and more resources availability to the wheat plants. Asad et al. (2017) also stated that increase in spike length attributed to minimum crop - weed competition in treated plots and more availability of moisture that cause healthy plant growth.

\section{Number of seeds per spike}

The application herbicides had no significant effect on number of seeds per spike but the maximum numbers of seeds per spike were counted at application of Pyroxulam (76.58) whereas minimum number of grains per spike was counted from weedy check plot (Table - 4).

The highest number of seeds per spike at application of Pyroxulam might be related to lower dry weed biomass, better weed control efficiency that contributed to the crop to have longer spikelets for producing more number of seeds. Lower number of seeds per spike can be attributed to shorter spike length in weedy check plots due to severe crop-weed competition.

Similar results have also been reported by Pandey et al. (2007) increase in number of grains per spike can be attributed to availability of nutrients and greater spike length of wheat. According to Ali et al. (2014) the number of seeds per spike increased with decreased weed competition. The poor grain filling due to presence of weeds was reported to be due to reduced tillering, ear formation, and stem weight and height reduction in wheat (Fazal et al., 2012).

\section{Thousand grain weight}

The application of different herbicides imposed significant effect on thousand grain weight. Maximum thousand grain weight was recorded at application of Pyroxulam (42.60gm) closely followed by use of 2, 4-D (41.20gm) while minimum number of thousand grain weight was recorded at weedy check (Table - 4).

The ANOVA result showed that the interaction of 2, 4-D and Pyroxulam caused statistically no significant difference and also application of Florasulam and Florasulam + Amirpyrolid showed statistically no significant differences. The highest thousand grain weight at Pyroxulam could be related to lower dry weed biomass, better weed control efficiency, minimum intra and inter-specific competition that enable the crop to utilize resources efficiently to produce well vigor seeds but at weedy check treatments lowest number of thousand grain weight was due to higher competition of plant growth resources that resulted in less vigor seeds.

Similar results from Pandey et al. (2007) reported that lower thousand grain weight in weedy check and availability of nutrients and better plant growth might be the reason for heavier grains in high fertilizer levels.

Table 4. Effects of herbicides application on spike length, number of seeds per spike and thousand grain weight

\begin{tabular}{|c|c|c|c|c|}
\hline Treatments & Spike length $(\mathrm{cm})$ & $\begin{array}{c}\text { Number of seeds per } \\
\text { spike }\end{array}$ & $\begin{array}{r}\text { Thousand grain } \\
\text { (gm) }\end{array}$ & weight \\
\hline $2,4-\mathrm{D}$ & $9.16 \mathrm{ab}$ & 66.58 & $41.20 \mathrm{ab}$ & \\
\hline Pyroxulam & $9.58 \mathrm{a}$ & 73.08 & $42.60 \mathrm{a}$ & \\
\hline Florasulam & $8.75 b$ & 68.33 & $39.06 \mathrm{c}$ & \\
\hline Florasulam+Amirpyrolid & $8.91 \mathrm{ab}$ & 69.16 & $39.86 \mathrm{Bc}$ & \\
\hline Weedy check & $7.58 \mathrm{c}$ & 65.33 & $28.40 \mathrm{~d}$ & \\
\hline $\operatorname{LSD}(0.05)$ & 0.78 & NS & 1.89 & \\
\hline $\mathrm{CV}(\%)$ & 4.73 & 8.91 & 2.63 & \\
\hline
\end{tabular}




\section{Grain yield}

The grain yield was significantly affected by the application of different herbicides. Maximum grain yield (4346.58 $\mathrm{kg} \mathrm{ha}^{-1}$ ) was obtained from Pyroxulam while minimum grain yield (1348.33 $\mathrm{kg} \mathrm{ha}^{-1}$ ) was obtained from weedy check (Table -5).

The application of Florasulam and Florasulam + Amirpyrolid showed that statistically no significant difference. The highest number of grain yield at Pyroxulam could be related to less weed competition with crop for plant growth factors and optimum space for wheat plants to flourish and produce fertile tillers up to their potential, more number of seeds per spike, thousand grain weight and higher number of total biomass production. The herbicide also had the ability of controlling various weed species and persistent. However, the lower grain yield at weedy check treatments was due to the severe inter and intra specific competition that resulted in lower yield and yield components.

The result of this study was similar with Nadeem et al. (2006) which stated that different herbicidal treatments had a significant effect on grain yield of wheat. The greatest reduction of yield was occurred when no herbicide was applied. Increased in yield in herbicides treated plots were due to the efficient weed control and thus the crop utilized all the available resources. These results are in confirmity with the work of Tunio et al. (2004) who reported that herbicidal treatments significantly increased grain yield in wheat. Ali et al. (2014) also stated that maximum grain yield was at weed free due to less weed population, better nutrient and water use efficiency but minimum at weedy check.

\section{Biological yield}

The application different post emergence herbicides highly influenced biological yield. The maximum biological yield was obtained from the combination of Pyroxulam (12100 kg ha-1) while minimum biological yield (5750 $\mathrm{kg} \mathrm{ha}^{-1}$ ) was obtained from weedy check (Table - 5).

The use of Florasulam and Florasulam + Amirpyrolid revealed that statistically no significant difference. The higher number of biological yield at application Pyroxulam could be related to less weed competition with crop plants for water, nutrients and other growth factors and also due to the optimum space for wheat plants to flourish and produce fertile tillers up to their potential, more number of seeds per spike and thousand grain weight that contributed to biological yield. However, the lowest biological yield at weed check signified severe competition of weeds resulted in fewer number of plants in plots.

Similar results were reported from Ali and Awan (2004) who stated that decreasing the biological yield in wheat might be due to weed competition as a consequence of depletion of nutrient supply and water by weeds, which resulted in reduced growth, seed and straw yields of crop plants. However, it is suggested that high seed rates were found to increase yield in well watered conditions, whereas the reverse was true with low soil moisture (Marwat et al., 2011).weed control methods increased biological yield of wheat reducing the weed infestation ( Zahoor et al.,2012).

Table 5. Effects of herbicides on grain yield, biological yield, harvest index and yield loss

\begin{tabular}{lcccc}
\hline Treatments & $\begin{array}{c}\text { Grain yield } \\
\left(\mathrm{kg} \mathrm{ha}^{-1}\right)\end{array}$ & $\begin{array}{c}\text { Biological yield } \\
\left(\mathrm{kg} \mathrm{ha}^{-1}\right)\end{array}$ & $\begin{array}{c}\text { Harvest index } \\
(\%)\end{array}$ & $\begin{array}{c}\text { Yield loss } \\
(\%)\end{array}$ \\
\hline 2,4-D & $3558.17 \mathrm{c}$ & $8000.00 \mathrm{c}$ & $32.53 \mathrm{a}$ & $14.57 \mathrm{~b}$ \\
Pyroxulam & $4346.58 \mathrm{a}$ & $12100.00 \mathrm{a}$ & $26.42 \mathrm{~b}$ & $3.75 \mathrm{~d}$ \\
Florasulam & $4053.83 \mathrm{~b}$ & $10433.30 \mathrm{~b}$ & $28.07 \mathrm{~b}$ & $10.23 \mathrm{c}$ \\
Florasulam+Amirpyrolid & $4034.75 \mathrm{~b}$ & $10566.70 \mathrm{~b}$ & $27.75 \mathrm{~b}$ & $10.66 \mathrm{c}$ \\
Weedy check & $1348.33 \mathrm{~d}$ & $5750.00 \mathrm{~d}$ & $18.99 \mathrm{c}$ & $70.14 \mathrm{a}$ \\
\hline LSD $(0.05)$ & 55.46 & 1130 & 2.28 & 1.23 \\
CV $(\%)$ & 0.83 & 6.4 & 4.53 & 2.98 \\
\hline
\end{tabular}

\section{Harvest index}

The application of different herbicides showed highly significant effect on harvest index. The highest harvest index $(32.53 \%)$ was observed at 2, 4-D.The minimum harvest index (18.99\%) was obtained from weedy check (Table $5)$.

The application of Pyroxulam, Florasulam and Florasulam +Amirpyrolid showed that statistically no significant differences. The maximum number of harvest index at 2, 4-D might be related to higher in total biomass production. The result also clearly indicated that harvest index was lower at higher total biomass production. Similar findings were reported from Ali et al.(2014) and Amare et al.(2014) concluded that harvest index increased with decreased in weed competition. Sujoy et al. (2006) was also reported that significant variation in harvest index of wheat due to weed control treatments.

\section{Yield loss}

The uses of various post emergence herbicides were highly significant on yield loss of bread wheat. The use of 
Pyroxulam gave the lowest yield loss $(3.75 \%)$ as compared to other tested herbicides but maximum yield loss was obtained from weedy check plots $70.14 \%$ (Table - 5).

The application of Florasulam and Florasulam + Amirpyrolid showed that statistically no significant differences. The lowest yield loss at Pyroxulam could be related to higher weed control efficiency, more number of yield components and better crop growing conditions to produce higher yield. In contrast, higher weed biomass resulted in greatest yield reduction due to competition for growth resources and fewer number of wheat in the plots.

The highest yield loss obtained from weedy check plots as a result of higher weed density and competition. The finding was in conformity with the work of Amare et al(2014) reported that highest yield loss was at weedy check and under poor weed control. On the other hand, Karlen et al (2002) reported a yield reduction as high as $80 \%$ in wheat due to weed competition throughout the crop growing season.

\section{SUMMARY AND CONCLUSION}

Wheat is one of major food grains that contain different nutrient and cultivated from small to large scale farms in Ethiopia. Weed management practices such as promising herbicides are among the important methods for the management of weeds to improve wheat production and productivity. Therefore, this study was designed to investigate the effects of post emergence herbicides application on weed growth and productivity of wheat.

All of the traits studied were significantly affected by different herbicides application except number of seeds per spike. The minimum number of dry biomass of weeds and weed control efficiency were recorded at application of Pyroxulam but no weed control at weedy check while the maximum numbers of dry biomass of weed were obtained from weedy checks. The maximum number of productive tillers, stand count, thousand grain weight, grain yield and biological yield were obtained from of Pyroxulam treated plots but no significant difference was observed due to applied herbicides on seeds per spike. The maximum plant height was recorded from of weedy check. The maximum harvest index was observed at 2, 4-D.

Application of Pyroxulam comparatively gave low significant yield loss as compared to other tested herbicides while highest yield loss was obtained at weedy check plots. Herbicides having the ability of controlling various weed species gave better yield advantages as well as for good weed management over narrow spectrum herbicides. Pyroxulam is recommended for controlling various weed species in wheat field at small scale and large scale farms. However, more yield advantages was obtained from application of broad spectrum herbicide Pyroxulam. Since the experiment was conducted for one season and location, it should be repeated over seasons or multiple locations for best recommendation.

\section{REFERENCES}

Abbas,S.H.,Saleem,M.,Maqsood,M.,Mujahid, M.Y. and Saleem, R.,2009.Weed density and grain yield of wheat as affected by spatial arrangements and weeding techniques under rainfed conditions of Pothowar. Pak. $J$. Agri. Sci, 46(4), pp.242-247.

Ahmad,K.,Z.Shah, I.Khan,M. Khan and Khan,M.Q.,1993.Effect of post-emergence herbicides application and hand weeding onwheat and weed pressure.Pak.J.Weed Sci. Res.6(1-2): 40-45.

Akhtar,M.,Q.,Hamayoun,M.B.,Gill and Nazir,M.S.,1991.Comparative Study of various crop management practices on the weed growth and wheat yield.Sarhad J. Agric.7(2): 91-94.

Ali,H.,Tahir,M.and Nadeem,M.A.,2014.Determining Critical Period of Weed Competition in Wheat under Different Tillage Systems.life, 12(2),pp.74-79.

Ali,Y.and Awan,A.R.2004.Influence of salinity at seedling stage on yield and yield components of different rice lines. International Journal of Biotechnology, Vol. 1: pp.175-179.

Amare,T.,Sharma,J.J. and Zewdie,K.,2014.Effect of weed control methods on weeds and wheat (Triticum aestivum L.) yield. World journal of agricultural research, 1(2), pp.124-128.

Asad, M.,Safdar, A., Ansar, M.R.,Ijaz, A.,Suhaib, M. and Abuzar, M.K., 2017. Weed and Wheat Dynamics Preceding Different Herbicide. Pakistan Journal of Agricultural Research, 30(4):346-355.

Ashiq,Muhammad,N.and Ahmad,N.,2007.Comparative efficacy of different herbicides against broadleaved weeds in wheat.Pakistan Journal of Weed Science Research, 13(3-4):pp. 149-156.

Bibi,S.,Marwat,K.B.,Hassan,G.and Khan,N.M.,2008. Effect of herbicides and wheat population on control of weeds in wheat. Pak. J. Weed Sci. Res,14(3-4),pp.111-119.

CSA.2018.Agricultural Sample Survey Series, 2017/18: Report on Area and Production for Major Crops(Private Holdings,Main Season).Statistical Bulletin No.586.Centeral Statistics Agency of Ethiopia,Addis Ababa, Ethiopia. pp.15-30.

Dalga, D.,2016. Weed Dynamics and Yield of Bread Wheat (Triticum aestivum L.) in response to weed management and nitrogen fertilizer rates in Southern Ethiopia. Scientia, 16(1), pp.8-19.

Davasenapathy,PT,Remesh,B.,2008.Efficiency indices for Agricultural Management Research. New Indian Publishing Agency,New Delhi India,pp.576-64.

Fazal, Munsif, Kawsar,Ali, Iftikhar and Khan,H.U., 2012.Efficacy of various herbicides against weeds and their 
impact on yield of spring wheat. Pakistan Journal of Weed Science. Research, 15(2-3): 191-198.

Gezu,G.andSoboka,H.,2001.Agronomic research recommendation and seed production maintenance techniques for major crops training manual for DA of highland Bale Sinan Ethiopia. pp.9-15.

Gomez,K.A.and Gomez ,A.A.,(1984).Statistical procedures for agricultural research (2 ed.). John wiley and sons, NewYork, 680p.

Hussain,Z.,Marwat,K.B.,Munsif,F.,Samad,A.and Ali,K.,2013.Evaluation of various herbicides and their combinations for weed control in wheat crop. Pak. J. Bot, 45(1), pp.55-59.

Karlen, L.D., Buhler, D.D., Ellusbury, M.M. and Andrews, S.S., 2002. Soil, weeds and insect management strategies for sustainable agriculture. Journal of Biological Science, 2(1) :58-62.

Khalil,Hassan,G.,Ahmad,G. and Hussain,S.N.,2008.Individual and combined effect of different weed management practices on weed control in Wheat. Pakistan Journal of Weed Science Research, 14 (3-4): 131139.

Khalil,Hassan,G.,Ahmad,G. and Hussain,S.N.,2009.Individual and combined effect of different weed management practices on weed control in Wheat.Pakistan Journal of Weed Science Research,14(3-4): 131139.

Marwat, K.B., Saeed, M.,Hussain,Z.,Gul, B. and Rashid,H.,2008. Study of various herbicides for weed control in wheat under irrigated conditions. Pak. J. Weed. Sci. Res, 14(2), pp.1-8.

Marwat,K.B., Khan,A,.M ,Hashim,S.,Nawab,K.And Abdul Mateen,K.K.,2011 . Integrated Weed Management In Wheat Pak. J. Bot., 43(1):pp. 625-633

Mathewos, A.,Tewodros,M. and Yasin,G.,2012. Participatory on-farm evaluation of improved bread wheat technologies in some districts of southern Ethiopia. Journal of Biology, Agriculture and Healthcare, 2(4): pp.85-91.

Munsif,F., Ali,K.,Khan,I., Khan,H.U.and Anwar,M.,2009.Efficacy of various herbicides against weeds and their impact on yield of maize. Pak. J. Weed Sci. Res, 15(2-3), pp.191-198.

Nadeem,M.A.,Ali,A. and Tanveer,A.S.I.F.,2006. Effect of different weed control practices and fertilizer levels on the weeds and grain yield of wheat. Pakistan Journal of Botany, 39(1), p.173.

Oerke, E.C. and Dehne, H.W., 2004. Safeguarding production-losses in major crops and the role of crop protection. Crop protection, 23(4), pp.275-285.

Pandey,I.B.and Dwivedi,D.K.,2007.Effect of planting pattern and weed-control methods on weed growth and performance of wheat (Triticum aestivum). Indian Journal of Agronomy,52(3),pp.235-238.

Qasem,J.R,2009. Wheat Genetics,Crops and Food Production. ISBN 978-1-61209-307-9,pp.1-7

Safdar, M.E., Asif, M., Ali, A., Aziz, A., Yasin, M., Aziz, M., Afzal, M. and Ali, A., 2011. Comparative efficacy of different weed management strategies in wheat. Chilean journal of agricultural research, 71(2),pp.195.

Sujoy, D.,Sarkar,A.K.,Bhattacharya,S.P.,Abhijit, S. 2006.Effect of various weed management practices in wheat. Environment and Ecology, 24: 620-622.

Tana,T.,Lemlem,M.and Dejene,M.,2018.Determination of Critical Period of Weed Competition in Bread Wheat Triticum aestivum L.at Haramaya,Eastern Ethiopia ,Doctoral dissertation,Haramaya University.pp.1-92

USDA, 2019. World Agricultural Production and Agricultural projections.Oxford University Press.pp.32

Zahoor, F.,Malik, M.A.,Mehmood, K.,Rasheed,M.,Ansar,R.,Hussain, M.,Kazmi,M.H. and Jamil, M.,2012.Optimizing herbicide use in wheat (Triticum aestivum L.) under rain-fed conditions. African Journal of Agricultural Research, 7(35), pp.4858-4866. 